\title{
Effect of Feeding Graded Levels of Carrot Tops Hay on Growth Performance of New Zealand White Rabbits
}

Sherif, Kh. El.; M. H. Rabie and A. I. Bedair

Poultry Production Department, Faculty of Agriculture, Mansoura University.

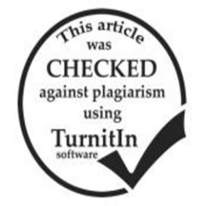

\section{ABSTRACT}

This experiment was designed to assess the possibility of using graded levels of carrot tops hay (CTH) in rabbit diets and its effect on growth performance, nutrient digestibility, carcass traits, economic efficiency and certain blood constituents. Sixty 6-week-old New Zealand White rabbits were randomly divided into 5 equal experimental groups, each with four equal replications and kept in cages in an open-sided rabbitry. Five experimental diets containing different levels $(0.0,10,20,30$ and $40 \%)$ of CTH were formulated and used from6 to14 weeks of age. The experimental animals were fed their experimental diets and clean drinking water ad libitum. The criteria of response (body weight, feed consumption, weight gain and efficiency of feed utilization) were estimated weekly on a replicate group basis. During the last week of study, five digestion trials were performed to estimate the nutrient digestibility of the experimental diets. When the rabbits were 14 weeks of age, 5 rabbits from each treatment were randomly selected and fasted for 18 hours before slaughtering. Carcass yield, giblets (liver, heart and kidneys) and total edible parts were estimated relative to LBW at slaughter. Some blood plasma parameters were also determined. The obtained results can be summarized as follows: Dietary inclusion of CTH up to $30 \%$ had no adverse effect on all criteria of growth performance of 14 -week-old rabbits. However, rabbits fed diet containing $40 \% \mathrm{CTH}$ had significantly lower final body weight and total gain compared with other experimental treatments. Dietary treatments had no significant effect on total feed intake or efficiency of feed utilization. Rabbits fed diets containing different levels of CTH achieved significantly better economic efficiency of feeding (EEF) compared with those fed on the control diet, the highest mean of EEF was achieved by rabbits received the $30 \%$ CTH-diet. There were significant differences in digestibility of dry matter (DM), organic matter $(\mathrm{OM})$ and ether extract (EE) among the experimental treatments, Inclusion of $\mathrm{CTH}$ at $40 \%$ significantly depressed the digestibility of $\mathrm{DM}, \mathrm{OM}$ and EE compared with other treatments. Feeding diets containing the CTH up to $30 \%$ did not negatively affect digestibility of nutrients. Dietary treatments did not significantly affect carcass traits (carcass yield, giblets and total edible parts ) or blood measurements. We can conclude that carrot tops hay can safely be used in growing rabbit diets up to $30 \%$ without any adverse effect on their performance or carcass traits.

Keywords: Carrot tops hay, growth performance, rabbits.

\section{INTRODUCTION}

Feeding cost of rabbits represents at least $65 \%$ of the total production cost. For optimizing the profitability of rabbit production, there is an urgent need to look for alternative plant by-products and evaluate their nutritive value for rabbits. Rabbits are herbivorous animals that consume high forage diets. Feeding rabbits on high fibrous agricultural by-products may be limited if their lignin fraction is high (Galal et al., 2014). Minimizing the feeding cost could be achieved through the use of untraditional cheaper feed ingredients. One possible solution to increase the animal protein production is the use of small ruminants and semi-ruminant species such as rabbits (Mahsoub, 2007). Intensive rabbit production in developing countries has been greatly affected by feeding costs, especially dietary protein and energy sources (Ezea, 2004). The CTH is one of unconventional feed ingredients. Therefore, this experiment was designed to investigate the effects of dietary inclusion of graded levels of $\mathrm{CTH}$ on performance, nutrient digestibility, carcass traits and some blood parameters of New Zealand White rabbits.

\section{MATERIALS AND METHODS}

\section{Experimental Procedures}

The current feeding trial was undertaken in the Rabbit Farm, at the Agricultural Research Center, belonging to Faculty of Agriculture, Mansoura University, during May to July, 2016. Carrot tops hay $(\mathrm{CTH})$ was used at levels of $0,10,20,30$ and $40 \%$ of the diet. The parameters examined included body weight, weight gain, feed consumption, feed conversion ratio, economic efficiency, nutrient digestibility, carcass traits and some blood constituents of rabbits.

\section{Experimental animals}

Sixty growing New Zealand White (NZW) rabbits, at 6 weeks of age, were randomly divided into 5 groups, each of 12 animals in three replicates of 4 rabbits each. All groups of rabbits had approximately equal initial live body weights. Each group of rabbits was fed on one of five experimental diets (Table1).

\section{Experimental diets}

The fresh carrot tops was collected and mechanically cut to small pieces, sun dried and used in the experimental diets. The chemical composition (as-fed basis) of carrot tops hay (CTH) was $93 \%$ dry matter, $78 \%$ organic matter, $18 \%$ crude protein, $0.005 \%$ ether extract, $12 \%$ crude fiber, $15 \%$ ash, and $37.99 \%$ nitrogen free extract. Five experimental diets in pelleted form were formulated to contain five levels of $\mathrm{CTH}(0,10,20,30$ and $40 \%$ ). The composition and chemical analysis of the experimental diets are presented in Table1.

\section{Rabbit housing and measurements}

Each replication of rabbits was housed in one cage supplied by a feeder and a nipple drinker. The cage dimensions are $50 \times 70 \times 50 \mathrm{~cm}$. All rabbits received the fresh water and their respective diets (pellets) on an ad libitum basis throughout the experimental period from 6 to 14 weeks of age. The experimental rabbits were kept under the same managerial and hygienic conditions. Live body weight and feed intake were recorded weekly on a replicate basis. Economic efficiency of feeding (EEF) was computed as price per one $\mathrm{kg}$ weight gain - feed cost $/ \mathrm{kg}$ gain / feed cost/kg gain)] multiplied by 100 . The sale price per unit of weight gain was 25.0 EGP. 
Sherif, Kh. El. et al.

$\underline{\text { Table 1. Ingredients and chemical analyses of the experimental diets }}$

\begin{tabular}{|c|c|c|c|c|c|}
\hline \multirow{2}{*}{ Ingredients } & \multicolumn{5}{|c|}{ Dietary CTH levels (\%) } \\
\hline & 0.00 & 10 & 20 & 30 & 40 \\
\hline Yellow corn & 13.0 & 10.15 & 7.9 & 5.70 & 3.7 \\
\hline Soybean meal, $44 \%$ CP & 13.1 & 12.00 & 10.5 & 8.75 & 7.3 \\
\hline Wheat bran & 29.0 & 24.00 & 19.0 & 14.00 & 9.0 \\
\hline Ground barley & 16.0 & 13.00 & 10.0 & 7.00 & 4.0 \\
\hline Alfalfa hay & 27.0 & 29.10 & 31.1 & 33.30 & 34.8 \\
\hline $\mathrm{CTH}^{\uparrow}$ & 0.0 & 10.00 & 20.0 & 30.00 & 40.0 \\
\hline Limestone & 1.2 & 1.00 & 0.6 & 0.20 & 0.00 \\
\hline Common salt & 0.3 & 0.30 & 0.3 & 0.30 & 0.3 \\
\hline Premix* & 0.3 & 0.30 & 0.3 & 0.30 & 0.3 \\
\hline Lysine & 0.0 & 0.00 & 0.1 & 0.20 & 0.3 \\
\hline DL-methionine & 0.1 & 0.15 & 0.2 & 0.25 & 0.3 \\
\hline Total & 100 & 100 & 100 & 100 & 100 \\
\hline \multicolumn{6}{|c|}{ Calculated analysis (As-fed basis): (NRC, 1977) } \\
\hline $\mathrm{DE} ; \mathrm{kcal} / \mathrm{kg}$ & 2541 & 2541 & 2548 & 2552 & 2560 \\
\hline Crude protein $(\mathrm{CP}) \%$ & 17.31 & 17.36 & 17.36 & 17.3 & 17.27 \\
\hline Crude fiber $\%$ & 12.76 & 14 & 15.22 & 16.47 & 17.55 \\
\hline Ether extract \% & 2.75 & 2.53 & 2.32 & 2.12 & 1.91 \\
\hline Calcium $\%$ & 0.91 & 1.04 & 1.08 & 1.13 & 1.25 \\
\hline Total P \% & 0.6 & 0.54 & 0.47 & 0.41 & 0.34 \\
\hline Lysine $\%$ & 0.81 & 0.74 & 0.76 & 0.78 & 0.8 \\
\hline Methionine \% & 0.33 & 0.36 & 0.38 & 0.41 & 0.43 \\
\hline Meth.+Cys. \% & 0.66 & 0.66 & 0.66 & 0.65 & 0.65 \\
\hline Price per kg (EGP) & 2.61 & 2.47 & 2.34 & 2.2 & 2.07 \\
\hline \multicolumn{6}{|c|}{ Determined analysis (Dry matter basis): } \\
\hline DM \% & 93.46 & 93.92 & 92.48 & 92.15 & 91.78 \\
\hline $\mathrm{CP} \%$ & 18.49 & 18.43 & 18.73 & 18.74 & 18.70 \\
\hline $\mathrm{CF} \%$ & 13.55 & 15.12 & 16.50 & 17.99 & 19.00 \\
\hline $\mathrm{EE} \%$ & 2.84 & 2.65 & 2.46 & 3.15 & 1.96 \\
\hline Ash \% & 9.90 & 10.06 & 10.48 & 10.81 & 11.00 \\
\hline OM \% & 83.56 & 83.86 & 82.00 & 81.33 & 80.75 \\
\hline NFE $\%$ & 48.69 & 47.66 & 44.30 & 41.47 & 40.98 \\
\hline
\end{tabular}

* Each kilogram contains: Vit.A, 2000000 IU; Vit.D ${ }_{3}, 150000$ IU; Vit.E, 8.33 mg; Vit.K, 0.33 mg; Vit.B 1 , 1.0 mg; Vit.B 2 , 1.0 mg; Vit. B, 8.33 mg; Vit.B $_{6}, 0.33 \mathrm{mg}$; Vit. $B_{12}, 1.7 \mathrm{mg}$; Choline chloride $20 \mathrm{~g}$; Niacin, 8.33 mg; Biotin, $33 \mathrm{mg}$; Folic acid, $0.83 \mathrm{mg}$ Pantothenic acid, $3.33 \mathrm{mg}$; Zn, 11.79 g; Fe, $12.5 \mathrm{~g}$; Cu, 0.5 g; Co, 1.33 mg; Se, $16.6 \mathrm{mg}$; Mg, $66.79 \mathrm{mg} ;$; and Mn, $5 \mathrm{~g}$. ๆ: CTH = Carrot tops hay.

\section{Digestion trials}

During the last week of the feeding trial, nutrient digestibility was estimated by means of five digestion trials. Four rabbits from each treatment were used in each trial. These rabbits were weighed and kept in metabolic cages. A preliminary period of 3 days was followed by a 3-day collection period of feces during which feed intake was accurately determined and cecotrophy was not prevented. Collection of feces began at 24 hours after offering the feed. The feces of each group of rabbits was collected every day in the morning. Any shaded hair or foreign materials were discarded. The feces was dried at 60 ${ }^{\circ} \mathrm{C}$ for 16 hours in a forced-drought oven. At the end of the collection period, dried feces for each group was mixed, ground and stored until chemical analysis. Diets and feces were analyzed for dry matter (DM), crude protein (CP), ether extract (EE), crude fiber (CF) and ash according to AOAC (1995) using duplicate samples. Digestibility of nutrients was calculated as follows:

(Nutrient intake - Nutrient excreted) $\div$ Nutrient intake $\times 100$. Slaughter test

At 14 weeks of age, five rabbits from each treatment were randomly chosen and slaughtered after fasting for 12 hours. Rabbits were immediately weighed before and after slaughtering. Then, they were skinned and emptied. The weights of carcass yield, giblets (liver, heart, kidneys) and total edible parts were recorded. Head of each rabbit was included in the carcass weight. All carcass traits were calculated as percentage of the pre-slaughter weight.

\section{Blood constituents}

At the end of the experiment (14 weeks of age), 5 rabbits were randomly selected from each treatment for blood sampling. Blood samples were collected during slaughtering into heparinized tubes. Then, plasma was separated by centrifugation at $3000 \mathrm{rpm}$ for 15 minutes. The blood plasma levels of total protein, albumin, globulin, glucose, triglycerides, cholesterol, high density lipoprotein cholesterol (HDL-C) and low density lipoprotein cholesterol (LDL-C), and activity of plasma aspartate aminotransferase (AST) and alanine aminotransferase (ALT) were determined by commercial kits, as described by Doumas et al. (1981), Doumas et al. (1971), Trinder (1969), Fossati and Prencipe (1982), Allain et al. (1974), Sawle et al. (2002) and Friedewald et al. (1972), respectively.

\section{Statistical analysis}

Data were statistically analyzed by one-way analysis of variance using SAS program (SAS, 2006). Significant differences among means were estimated using Duncan's multiple range test (Duncan, 1955). 


\section{RESULTS AND DISCUSSION}

\section{Growth performance of rabbits}

Effects of feeding graded levels of CTH on growth performance of NZW rabbits during the experimental period (6-14 weeks of age) are presented in Table 2 . There were no significant differences in initial live body weights among the experimental groups of rabbits. Dietary inclusion of CTH up to $30 \%$ had no adverse effect on all criteria of growth performance of 14-week-old rabbits.
However, rabbits fed diet containing 40\% CTH had significantly lower final body weight and total weight gain compared with other experimental treatments. Dietary treatments didn't significantly affect total feed consumption or feed conversion efficiency. Rabbits fed diets containing different levels of CTH positively affected the EEF compared with those fed on the control diet; the highest EEF was recorded by rabbits received the 30\% CTH-diet.

Table 2.Effect of dietary CTH on growth performance of NZW rabbits from 6-14 weeks of age.

\begin{tabular}{lcccccc}
\hline $\begin{array}{l}\text { Dietary CTH levels } \\
\text { (\%) }\end{array}$ & $\begin{array}{c}\text { Initial body } \\
\text { weight (g) }\end{array}$ & $\begin{array}{c}\text { Final body } \\
\text { weight(g) }\end{array}$ & $\begin{array}{c}\text { Total } \\
\text { Weight gain(g) }\end{array}$ & $\begin{array}{c}\text { Total } \\
\text { feed intake(g) }\end{array}$ & $\begin{array}{c}\text { FCR } \\
(\mathbf{g : g})\end{array}$ & $\begin{array}{c}\text { EEF } \\
(\%)\end{array}$ \\
\hline T1 (control) & 635 & $1999^{\mathrm{a}}$ & $1356^{\mathrm{a}}$ & 5919 & 4.33 & $121^{\mathrm{c}}$ \\
T2 (10.0) & 629 & $2036^{\mathrm{a}}$ & $1407^{\mathrm{a}}$ & 5879 & 4.19 & $142^{\mathrm{b}}$ \\
T3 (20.0) & 637 & $2027^{\mathrm{a}}$ & $1319^{\mathrm{a}}$ & 5842 & 4.20 & $154^{\mathrm{ab}}$ \\
T4 (30.0) & 625 & $2017^{\mathrm{a}}$ & $1392^{\mathrm{a}}$ & 5894 & 4.23 & $168^{\mathrm{a}}$ \\
T5 (40.0) & 633 & $1860^{\mathrm{b}}$ & $1227^{\mathrm{b}}$ & 5945 & 4.48 & $149^{\mathrm{b}}$ \\
\hline SEM & 8.5 & 20.20 & 20.95 & 33.62 & 0.15 & 4.86 \\
\hline Significance level & NS & $*$ & $*$ & NS & NS & $* *$ \\
\hline
\end{tabular}

a-c: Means in the same column with different superscripts differ significantly $(\mathrm{P} \leq \mathbf{0 . 0 5})$.

NS = Not significant. SEM = Standard error of the means. FCR $=$ Feed conversion ratio.

The obtained results are in accord with Abdu et al. (2012), who found that feeding rabbits on diets containing up to $45 \%$ of carrot leaf meal had no significant effects on their final body weight, weight gains or economic efficiency. In addition, Abonyi et al.(2012) found that feeding rabbits on diets containing graded levels of sweet potato leaves (SPL) up to $50 \%$ had no adverse effect on final body weight, weight gain, feed intake or feed conversion of rabbits but when its level reached 75 or $100 \%$ feed intake increased while feed conversion ratio was negatively affected. Also, Genedy et al. (2000) suggested that feeding dried watermelon by-productcontaining diets up to $12 \%$ didn't significantly influence the body weight gain of rabbits compared with the control ones. Our results agree also with the findings of Safwat (2010) that BWG of rabbits was not significantly affected by feeding dietary containing corn cobs and field beans. Similarly, Asar et al. (2010) demonstrated that body weight gains of rabbits weren't influenced by either commercial diet or those contained two fiber sources (corn-cob meal and Faba bean straw) during the experimental period. Also, Ibrahim (2005) reported that LBW and BWG of rabbits were improved in response to feeding diets containing medicinal and aromatic plants.

As regards total feed intake of rabbits, it was not affected by the dietary treatments during the fattening period (6-14 week of age). In agreement with the present results, Kagya-Agyemang et al. (2013) who observed no significant influence on feed intake when rabbits were fed on dried pito mash as a replacement for maize. Similarly, Rabieet al. (2011) demonstrated that neither dietary fiber level nor probiotic addition had a significant impact on feed intake of rabbits during the post wearing period. In addition, Abdu et al. (2012) reported that feeding diets containing graded levels of carrot leaf meal up to $60 \%$ did not significantly affect daily feed intake of rabbits. On the contrary, Tag El-Din et al. (2002) found that rabbits fed 30\% Phaseolus vulgaris-containing diet from 4-14 weeks of age consumed more feed than did the control group.
In the present study, there were no significant differences in FCR among the experimental groups of rabbits from 6 to 14 weeks of age. This result is in agreement with the findings of Kagya-Agyemang et al. (2013) that feeding diets containing up to $20 \%$ dried pito mash did not alter the FCR of rabbits. In agreement with the present results, Mohsen et al. (2015) found that FCR of rabbits was not affected by replacing a commercial feed with hydroponic green barley forage.

On the contrary, El-Neneyet al. (2013) reported that FCR of rabbits significantly improved following to increasing dietary crude fiber to $18 \%$ compared with the control group. Similarly, Asar et al. (2010) reported an improvement in FCR of rabbits due to feeding diets containing corn-cob meal and Faba bean compared with their control rabbits. In addition, Bahnas et al. (2009) reported that rabbits fed parsley-containing diets had significantly better FCR compared with their control counterparts. Also, Hamed and Badr (2013) suggested that FCR was improved when berseem hay was replaced by pea straw at different levels.

Our results showed that the best EEF value was recorded for T4 $(30 \% \mathrm{CTH})$. In a good harmony with the present results, Abdu et al. (2012) found that feeding rabbits on diets containing carrot leaves hay led to a decrease in the total cost of the diet. Also, Galalet al. (2014) reported that the use of strawberry vine hay in rabbit ration led to an increase in the EEF. Similarly, Asar et al. (2010) found significantly better EEF when rabbits were fed on diets containing corn-cob meal compared with their control group. Also, Gaafar et al. (2014) obtained the highest total and net revenue values when berseem hay was partially replaced by ensiled and dried sweet potato vines in growing rabbits diets.

\section{Nutrient digestibility of rabbits}

The effects of feeding diets containing graded levels of CTH on nutrient digestibility of 13 weeks old rabbits are presented in Table 3. There were significant differences among the experimental treatments in DM, OM, and EE 
digestibility. Rabbits fed the diet containing the highest level of CTH (40\%) had the lowest digestibility of DM, OM and EE compared with other dietary treatments. But there dietary treatments had no significant impact on $\mathrm{CP}, \mathrm{CF}$ and NFE digestibility of rabbits.

In partial disagreement with our results, Abd ElLatif et al. (2012) reported that when sugar beet pulp was used as replacement of hay in rabbit diets the digestibility of DM, OM, EE and NFE were not affected but CF and CP digestibility were significantly improved due to increasing dietary sugar beet pulp up to $75 \%$ compared with those fed the basal diet. On the other hand, Abonyiet al. (2012) found that inclusion of sweet potato leaves up to $100 \%$ in rabbit diets significantly improved DM digestibility but the $\mathrm{CP}$ and EE digestibility were not affected. Also Sherif et al. (2008) found that digestibility coefficients of CP and NFE were not affected by feeding rabbits on banana leaves, however $\mathrm{CF}$ digestibility was improved compared with the control group.

Table 3. Effects of feeding diets containing different levels of CTH on nutrient digestibility of 13-week-old NZW rabbits

\begin{tabular}{lcccccc}
\hline $\begin{array}{l}\text { Dietary CTH levels } \\
\text { (\%) }\end{array}$ & DM & OM & CP & EE & CF & NFE \\
\cline { 2 - 7 } & $84.78^{\mathrm{a}}$ & $86.18^{\mathrm{a}}$ & 85.37 & $90.42^{\mathrm{a}}$ & 50.24 & 94.32 \\
T1 (control) & $83.98^{\mathrm{a}}$ & $85.84^{\mathrm{a}}$ & 85.15 & $89.36^{\mathrm{a}}$ & 46.30 & 94.68 \\
T2 (10.0) & $83.78^{\mathrm{a}}$ & $85.58^{\mathrm{a}}$ & 84.84 & $88.47^{\mathrm{a}}$ & 45.35 & 93.66 \\
T3 (20.0) & $84.15^{\mathrm{a}}$ & $85.16^{\mathrm{a}}$ & 85.32 & $88.24^{\mathrm{a}}$ & 50.14 & 94.04 \\
T4 (30.0) & $80.89^{\mathrm{b}}$ & $82.83^{\mathrm{b}}$ & 85.11 & $83.86^{\mathrm{b}}$ & 51.51 & 93.69 \\
T5 (40.0) & 1.22 & 1.19 & 1.12 & 1.26 & 2.28 & 0.27 \\
SEM & $*$ & $*$ & NS & $* *$ & NS & NS \\
Significance level & $*$
\end{tabular}

${ }^{a-b}$ Means in the same column with different superscripts are differ significantly $(P \leq 0.05) . ~ N S=$ Not significant, $S E M=S t a n d a r d$ error of the means

\section{Carcass traits}

Table 4 shows means of carcass traits of 14-weekold NZW rabbits as affected by dietary CTH level. Dietary treatments didn't affect the relative weights of carcass yield, kidneys, heart and total edible parts of rabbits. But rabbits received the lowest level of CTH had significantly higher percentages of liver and giblets weights than those of other dietary treatments.

Table 4. Carcass traits of NZW rabbits as affected by dietary leaves of CTH at 14 weeks of age

\begin{tabular}{lccccccc}
\hline \multirow{2}{*}{$\begin{array}{l}\text { Dietary CTH levels } \\
\text { (\%) }\end{array}$} & $\begin{array}{c}\text { Fast live } \\
\text { weight }(\mathbf{g})\end{array}$ & $\begin{array}{c}\text { Carcass } \\
\text { yield }\end{array}$ & Giblets & Liver & Kidneys & Heart & TEP \\
\hline T1 (control) & 1991 & 59.57 & $3.59^{\mathrm{b}}$ & $2.78^{\mathrm{b}}$ & 0.58 & 0.259 & 63.17 \\
T2 $(10.0)$ & 1971 & 57.69 & $4.02^{\mathrm{a}}$ & $3.41^{\mathrm{a}}$ & 0.62 & 0.259 & 61.71 \\
T3 $(20.0)$ & 1898 & 57.87 & $3.65^{\mathrm{ab}}$ & $2.80^{\mathrm{ab}}$ & 0.59 & 0.254 & 61.53 \\
T4 (30.0) & 1893 & 57.87 & $3.65^{\mathrm{ab}}$ & $2.78^{\mathrm{ab}}$ & 0.60 & 0.264 & 61.32 \\
T5 (40.0) & 1936 & 58.45 & $3.71^{\mathrm{ab}}$ & $2.82^{\mathrm{ab}}$ & 0.62 & 0.269 & 62.17 \\
\hline SEM & 84.17 & 0.80 & 0.12 & 0.11 & 0.02 & 0.02 & 0.79 \\
\hline Significance level & $\mathrm{NS}$ & $\mathrm{NS}$ & $*$ & $*$ & $\mathrm{NS}$ & $\mathrm{NS}$ & NS \\
\hline
\end{tabular}

${ }^{\mathrm{a}-\mathrm{b}}$ Means in the same column having different superscripts are significantly different $\mathrm{NS}=$ Not significant, $\mathrm{SEM}=\mathrm{Standard}$ error of the means, TEP $=$ Total edible parts.

Our results agree also with those of Ngoshe et al. (2013), who observed a significant difference in liver weight of rabbits fed graded levels of carrot leaf meal. In partial agreement with the present findings, Rabie et al. (2011) found no significant effect of dietary fiber levels on carcass traits of rabbits. Also Kagya-Agyemang et al. (2013) demonstrated that using dried pito mash in place of maize in rabbit diets had no significant effect on the relative weights of heart and kidneys. Also, Sherif et al. (2008) reported that carcass traits weren't affected by feeding rabbits with different levels of banana leaves. On the other hand, Amber et al. (2002) reported that dressing percentage was significantly lower for rabbits fed diets contained sugar beet pulp, sweet potato tops or mung bean hay than those received the control diet or the diet contained rice straw.

\section{Blood parameters}

Table 5 shows means of blood plasma parameters of 14-week-old NZW rabbits as affected by dietary CTH level. There were no significant differences among dietary treatments in blood plasma parameters including total protein, albumin, globulin, glucose, triglycerides, cholesterol, HDL, LDL-C, VLD-L or the activity of AST and ALT enzymes. The obtained results fall in the physiological range for rabbits.

Our results are in harmony with Rabie et al. (2011), who showed that the dietary fiber level had no significant effect on all blood plasma constituents. Also, Sherif et al. (2008) found that blood plasma parameters were not affected by feeding rabbits with different levels of banana leaves as a source of fiber. In the same line, Abdu et al. (2012) found that no significant differences among treatments in the cholesterol values of rabbits fed graded levels of carrot leaf meal. The obtained results of blood plasma constituents fall in the physiological range for rabbits. 
Table 5. Some blood plasma constituents for 14-week-old NZW rabbitsas affected by dietary level of CTH

\begin{tabular}{|c|c|c|c|c|c|c|c|}
\hline \multirow{2}{*}{ Treatments } & \multicolumn{5}{|c|}{ Dietary levels of CTH (\%) } & \multirow{2}{*}{ SEM } & \multirow{2}{*}{$\begin{array}{l}\text { Sign. } \\
\text { level }\end{array}$} \\
\hline & 0.0 & 10 & 20 & 30 & 40 & & \\
\hline Total protein $(\mathrm{g} / \mathrm{dl})$ & 5.62 & 5.87 & 5.96 & 5.68 & 5.43 & 0.22 & NS \\
\hline $\operatorname{Albumin}(\mathrm{g} / \mathrm{dl})$ & 3.08 & 3.24 & 3.33 & 3.10 & 2.99 & 0.15 & NS \\
\hline Globulin (g/dl) & 2.54 & 2.63 & 2.63 & 2.58 & 2.44 & 0.10 & NS \\
\hline Glucose (mg/dl) & 121.7 & 116.6 & 115.5 & 111.9 & 117.3 & 3.53 & NS \\
\hline Triglycerides (mg/dl) & 71.67 & 75.64 & 77.26 & 69.49 & 69.81 & 3.36 & NS \\
\hline Cholesterol (mg/dl) & 87.72 & 89.52 & 87.58 & 86.22 & 86.31 & 3.35 & NS \\
\hline $\mathrm{HDL}-\mathrm{C}(\mathrm{mg} / \mathrm{dl})$ & 27.46 & 28.72 & 32.11 & 30.45 & 30.83 & 1.65 & NS \\
\hline LDL-C (mg/dl) & 45.91 & 45.61 & 40.01 & 41.88 & 41.51 & 2.13 & NS \\
\hline VLD-L (mg/dl) & 14.35 & 15.13 & 15.45 & 13.89 & 13.96 & 0.67 & NS \\
\hline $\operatorname{ALT}(\mathrm{U} / \mathrm{L})$ & 12.44 & 12.14 & 12.31 & 12.47 & 12.43 & 0.66 & NS \\
\hline AST (U/L) & 50.70 & 48.09 & 48.15 & 48.21 & 48.82 & 1.91 & NS \\
\hline
\end{tabular}

NS = Not significant, SEM= Standard error of the means.

\section{REFERENCES}

Abd EL-Latif, S.A.; M.A Toson; Aattiat, EL Bogdadih and M.Kh. Abdel-Rahman (2012). Effect of replacing hay by sugar beet pulp in growing rabbit diets on some productive, metabolic responses and economic efficiency. Egyptian J. Anim. Prod., 47: 141-149.

Abdu, S.B.; G.E. Jokthan ; M.R. Hassan; H.Y. Adamu; S.M. Yashim, and E. Ikani (2012). Effects of inclusion levels of carrot (daucuscarota) leaf meal on performance of growing rabbits. World J. Life Sci. and Medical Research. 2 (2): 65-70.

Abonyi, F.O.; E.O. Iyi and N.S. Machebe (2012). Effects of feeding sweet potato (Ipomoea batatas) leaves on growth performance and nutrient digestibility of rabbits. African Journal of Biotechnology, 11(15): 3709-3712.

Aduku, A.O. and J.O. Olukosi (1990). Rabbit management in the tropics: production, processing, utilization, marketing, economics, practical training research and future prospects GU publications, Abuja, Nigeria. 68 pp.

Allain, C.C.; L.S. Poon; C.S.G. Chan; W. Richmond and P.C. Fu (1974). Enzymatic determination of total serum cholesterol.Clinical Chemistry. 20(4): 470475.

Amber, Kh.; N.S. Isshak and Niamat M. El-Abd (2002). Effects of dietary fiber source on performance of growing New Zealand white rabbits. Egypt. Poult. Sci. 22:127-146.

AOAC; Association of Official Analytical (1995). Official methods of analysis. $16^{\text {th }}$ ed., Association of Official Analytical chemists, Washington, DC, USA.

Asar, M.A.;O. Mona, H.M.Yakout and A. Safoat (2010). Utilization of corn-cob meal and faba bean straw in growing rabbit diets and their effect on growth performance, digestibility and economical efficiency. Egypt. Poult. Sci. 30(2): 415-442.

Bahnas, M.S.; M. S. Ragab ; N.E.A. Asker and Emam, R.M.S. (2009). Effect of using parsley or its byproduct with or without enzyme supplementation on performance of growing Japanese quails. Egypt. Poultry science 29(I): 241-262.

Cheeke, P.R. (1987).Rabbit Feeding and Nutrition, 1st ed. Academic Press, INC., London, UK.
Doums, B.T.; D.D. Bayse; R.J. Carter; T. Peters and R. Schaffer (1981). A candidate reference method for determination of total protein in serum. Development and validation. Clinical Chemistry, 27(10): 16421650.

Doums, B.T.; W.A. Watson and H.G. Biggs (1971).Albumin standards and the measurement of serum with bromocresol green. Clin. Chim. Acta, 31 :87-96.

Duncan, D. B. (1955): The Multiple Range and Multiple F. Test. Biometrics, 11, 1-42.

EL-Nattat. W.S. and R.I. EL-Kady (2007). Effect of different medicinal plant seeds residues on the nutritional and reproductive performance of adult male rabbits. Int. J. Agri. Biol., 9(3):479-485.

El-Neney, B.A.M.; Kh. I.I. Zeedanand A.I. Abd EL. Lateif (2013).The effect of different levels of dietary fiber fractions on performance and immunity of growing rabbits Egypt. Poult. Sci. 33(I): 51-71.

Ezea J.(2004). Effects of graded levels of toasted lima bean (Phaeluslunatus) meal in weaner rabbit diets B.agric. Thesis College of Animal Science and Health, Michael Okpara University of Agriculture. 57.

Fossati, P. and L. Prencipe (1982). Serum triglycerides determined colorimetrically with an enzyme that produces hydrogen peroxide. Clinical Chemistry, 28(10): 2077-2080

Friedewald WT, Levy RT, Frederickson DS. (1972). Estimation of the concentration of low-density lipoprotein cholesterol in plasma without use of the preparative ultracentrifuge Clin. Chem., 18: 499-502

Gaafar, H.M.A.; Abd El-Lateif, A.I.A. andAbd El-Hady, Salwa B.(2014). Effect of partial replacement of berseem hay by ensiled and dried sweet potato vines on performance of growing rabbits. Rep Opinion 6(8): 60-66]

Galal, H.M.F.; M.A. El Menniawy; M.H. Abo-Fadel; A.A. Khirand Safaa N. Abdel -Azeam (2014). Some nutritional studies on using strawberry (fragaria $\times$ ananas) vine as hay in rabbit ration. J. Animal and Poultry Prod., Mansoura Univ., 5(12): 635-647.

Genedy, Salwa, G.K.; M.S.M. Radwan; A.E. AboZeid and G.A Zanaty(2000).Feeding rabbits dried watermelon by-product (CitrullusLanatus Var.) as a replacing feed for clover hay. $8^{\text {th }}$ Agricultural Development Research Conference, November.20-22,Faculty of Agriculture, Ain Shams University, Egypt. 
Hamed A.A Omer andAzza M.M. Badr (2013). Growth Performance of New Zealand White Rabbits Fed Diets Containing Different Levels of Pea Straw. Life Science Journal 10(2). 1815-1822.

Ibrahim, Sh. A.M. (2005). Effect of some medicinal plants as feed additives on growth and some metabolic changes in rabbits.Egypt. J. Nutr. and Feeds. 8: 207217.

Ibrahim, Sh. A.M.; A.T. El-Yamanyand .A. M.M. Zeid (2004). Dill and Parsley as growth promoters in White New Zealand growing rabbits. Egypt. Poult. Sci., 24: 917-927.

Kagya-Agyemang, J.K. ; A. Nelson and C. KagyaAgyemang (2013). Growth performance of weaner rabbits fed on dried Pito mash as a replacement for maize. ARPN Journal of Agricultural and Biological Science. 8(4). 267-272.

Mahsoub, H.M.M. (2007). Some factors affecting productive traits in $\mathrm{V}$ line rabbits raised under Egyptian conditions. M. Sc. Thesis, Faculty of Agriculture, Alexandria University, Egypt.

Mohsen, M.K.; E.M. Abdel-Raouf; H.M.A. Gaafar, and A.M. Yousif, (2015). Nutritional evaluation of sprouted barley grains on agricultural by-products on performance of growing New Zealand white rabbits. Nat Sci. 13(10). 35-45.

Ngoshe, A.A.; J.U. Igwebuike and S.B Adamu (2013). Effects of feeding carrot (DaucusLcarota) leaf meal on hematology, blood chemistry and carcass characteristics of growing rabbits in a semi-arid environment of Borno state of Nigeria. Pakistan Journal of Nutrition 12(1). 12-19.

Rabie, M.H.; Kh. El. Sherif; M.A.A. Hussein, andAzza R.F. El-Desouqi (2011). Growth performance of rabbits as affected by dietary fiber level and probiotic addition during the post weaning period. J. Animal and Poultry Prod., Mansoura Univ. 2 (6).185-199.
Reitman, S. and S. Frankel, (1957). A colorimetric method for the determination of serum glutamic oxalacetic and glutamic pyruvic transaminases. Am. J. Clin. Pathol. 28. 56-63.

Safwat, A.M. (2010). Effect of using corn -cobs meal and dried offal of field bean in growing rabbit diets on growth performance, digestibility coefficients, carcass traits and economic efficiency. M.Sc. Thesis, poultry production Dept. Faculty of Agric. Alexandria University.

SAS Institute (2006). SAS/STAT User's Guide. Release 9.1.SAS Inst. Inc., Cary, NC.

Sawle A, Higgins MK, Olivant MP, Higgins JA.(2002). A rapid single step centrifugation method for determination of HDL, LDL, and VLDL cholesterol, and TG, and identification of predominant LDL subclass. J Lipid Res;43:335-43.

Sherif, Kh. El.; T.H., Tag El-Din; El-Samrah H.AAbo.Eglaand H. Abd-EL-Khalik. (2008). Performance of growing male rabbits fed diets containing banana leaves and yeast culture. Egyptian Rabbit. Sci. 18(2). 83-93.

Tag El-Din,T.H.;Kh.,El Sherief; El-Samrah H.A-Abo.Egla and Hassan H.A. (2002). Effect of using graded levels of (phaseolus vulgaris) straw in in NZW rabbits diets. Third Sci. Conf. on rabbit production in Hot Climats.8-11, Hurghada, Egypt; 643-653.

Trinder, P. (1969). Determination of glucose in blood using glucose oxidase with an alternative oxygen acceptor. Annals of Clinical Biochemistry, 6: 24-27.

Volek, Z.; V. Skřivanovaand M. Marounek (2004). Comparison of diets for growing rabbits containing potato pulp, sugar beet pulp and wheat bran: effect on performance and digestion parameters Arch. Geflügelk. (68): 259-264.

\section{تأثير التغذية على مستويات متدرجة من دريس عروش الجزر على الأداء الإنتاجي للأرانب التيوزيلاندى البيضاء

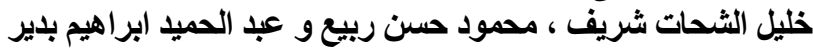 قسم إنتاج الدواجن ، كلية الزراعة ، مدئ ، جامعة المنصورة.}

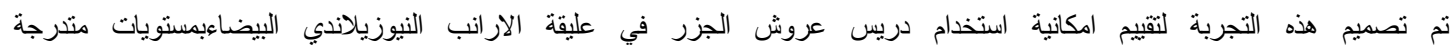

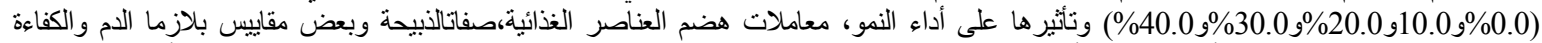

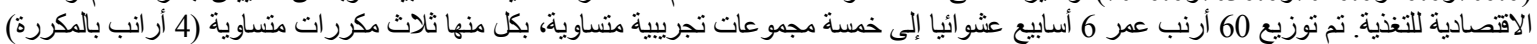

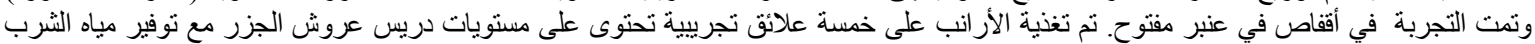

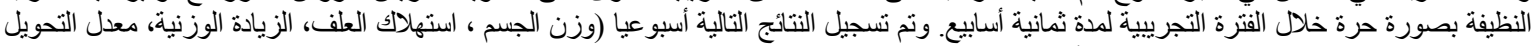

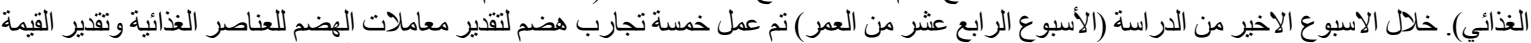

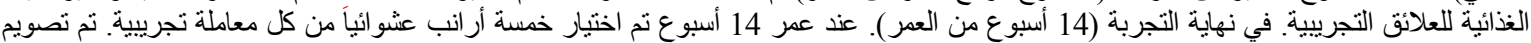

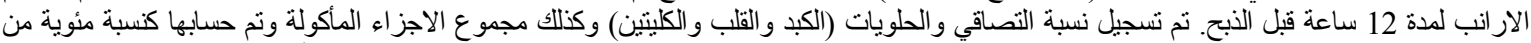

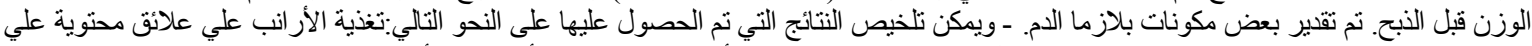

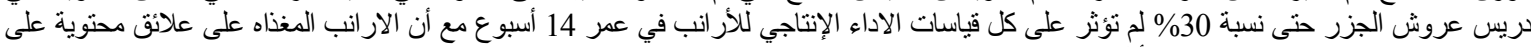

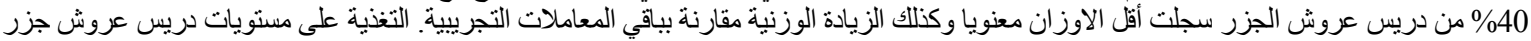

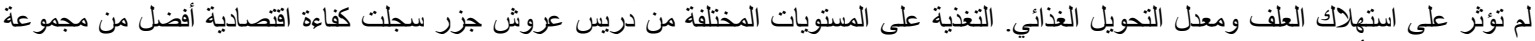

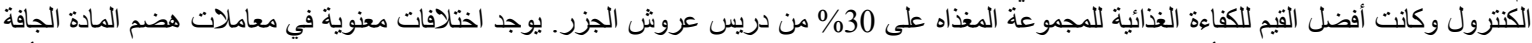

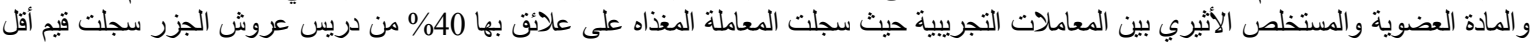

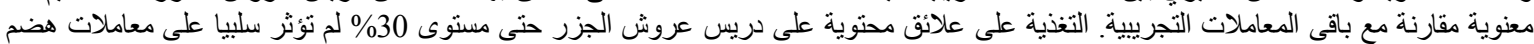

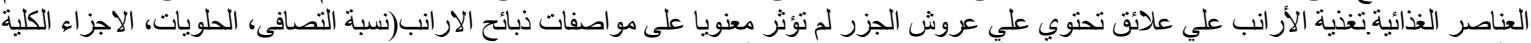

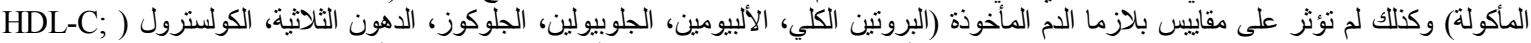

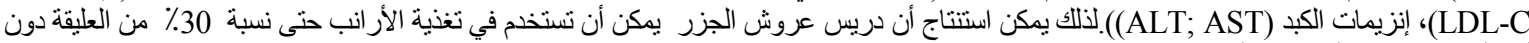
أي تأثير سلبي على أداء النمو أو صفات الذبيحة. 